\title{
The United Nations Convention on the Law of the Sea in the Present Geo-Political Situation
}

\author{
Hans Corell
}

\section{Keywords}

United Nations Convention on the Law of the Sea - geo-political - International Seabed Authority - International Tribunal for the Law of the Sea-Commission on the Limits of the Continental Shelf - intergovernmental conference - marine biodiversity - areas beyond national jurisdiction - Arctic

\section{1 \\ The United Nations Convention on the Law of the Sea}

Adopted in Montego Bay, Jamaica, on 10 December 1982, this treaty with this well-known acronym UNCLOS is surely one of the most important treaties in the world. At present, there are 168 parties to U NCLOS. Among the UN Member States there are 28 that are still not parties. Fifteen of these States are landlocked, so they may not be so interested in ratifying or acceding to the treaty. ${ }^{1}$ However, the remaining thirteen States are the following: Cambodia, Colombia, the Democratic People's Republic of Korea, El Salvador, the Islamic Republic of Iran, Israel, Libya, Peru, the Syrian Arab Republic, Turkey, the United Arab Emirates, the United States of America, and Venezuela. The question I always ask myself is whether the United States of America belongs in this group?

For my part, I have a very determined opinion about the importance of this Convention. I was not involved in the negotiations of the same. However, I had the honour of chairing the delegation of my country, Sweden, when we negotiated the delimitation of the exclusive economic zones in the Baltic Sea in the 198 os with the then-Soviet Union, Poland and Finland.

In March 1994, I became the Legal Counsel of the United Nations. This meant that I had the privilege of chairing the final consultations on Part XI of

1 These land-locked States are: Afghanistan, Andorra, Bhutan, Burundi, the Central African Republic, Ethiopia, Kazakhstan, Kyrgyzstan, Liechtenstein, Rwanda, San Marino, South Sudan, Tajikistan, Turkmenistan, and Uzbekistan. 
UNCLOS that resulted in an agreement that was adopted by the UN General Assembly on 28 July 1994. During these consultations I had great support from Satya Nandan of Fiji.

The UNCLOS entered into force on 16 November 1994, which meant that the three organs under the Convention: the International Seabed Authority in Kingston, Jamaica, the International Tribunal for the Law of the Sea in Hamburg, Germany, and the Commission on the Limits of the Continental Shelf that works in New York had to be established. This task fell upon the Division for Ocean Affairs and the Law of the Sea (DOALOs) in the United Nations Office of Legal Affairs. Consequently, I had to oversee this process-a very rewarding experience.

The International Seabed Authority (ISA) was already established in 1994. The International Tribunal for the Law of the Sea (ITLOS) was established in 1996, and the Commission on the Limits of the Continental Shelf (CLCS) held its first meeting in New York in June 1997.

Since I retired from the United Nations and public service in 2004, I have been able to follow these three organs at a distance only. With respect to UNCLOS my main focus since then has been on the polar regions. I had the privilege of chairing the 28th Antarctic Treaty Consultative Meeting in 2005. However, my attention has been on the Arctic in particular. The reason is that there are often misunderstandings in the media about the legal regime that applies there. It is therefore of great importance to clarify that the legal regime in the Arctic is UNCLOS. All the Arctic States except the United States are parties to UNCLOS.

There is often talk about disputes among the Arctic States. However, they are all aware of the legal regime that applies there, and even if the United States is not a party to UNCLOS it respects the rules of the Convention. As a matter of fact there is a direct reference to "the law of the sea" in the so-called Ilulissat Declaration, adopted by the five Arctic coastal States on 28 May 2008. ${ }^{2}$ The Declaration concerns the applicability of the law of the sea in the Arctic Ocean.

And disputes relating to the Arctic area have so far been settled through negotiations. At present, there are only two territorial disputes that I am sure will be resolved through friendly settlements. One concerns Hans Island in the sea between Greenland and Ellesmere Island in Canada. The other concerns the delimitation of the territorial sea and the exclusive economic zone between the United States (Alaska) and Canada, where Canada maintains that it should

2 See https://cil.nus.edu.sg/wp-content/uploads/formidable/18/20o8-Ilulissat-Declaration. pdf. 
follow the 141st azimuth while the United States maintains that it should follow the equidistance line.

As we know, the Commission on the Limits of the Continental Shelf shall make recommendations to States on the outer boundaries of the shelf when it extends beyond 200 nautical miles. In the media there is often reference to claims in the Arctic Ocean. And there will certainly be competing claims as, for example, in the case of Canada, Denmark (because of Greenland) and the Russian Federation. The duty of the Commission is to make recommendations with respect to how far out in the sea the shelf can be claimed. With respect to overlapping claims, these are questions that must be settled between the competing States. I have no doubt that the States in question will follow the rules that apply. So far, I note that they have made notifications relating to such claims in conformity with UNCLOS.

Now, a few words about the three organs of UNCLOS.

\section{a}

\section{The International Seabed Authority}

The International Seabed Authority has a very demanding responsibility with respect to the so-called Area or as it is often referred to "the common heritage of mankind". This is the area outside the territorial jurisdiction of States. According to article 153 of UNCLOS, activities in the Area shall be carried out and controlled by the Authority on behalf of mankind as a whole. The article contains rules about the manner in which these activities shall be carried out. In article 170 we find rules about the so-called Enterprise, which shall be the organ of the Authority which shall carry out activities in the Area.

The task of the Authority is indeed demanding. The First Part of the 25th Annual Session of the Authority took place from 25 February to 1 March 2019. The Authority has issued a summary of this meeting which is very interesting reading indeed. The summary also contains a brief analysis of the meeting focusing on The Economic Model, The Enterprise, Environmental Concerns, and Leaving No One behind, and focusing on the concerns of developing countries that have less capacity to equitably participate in the work of the Authority. Let me quote the last paragraph in the introduction to this summary:

This brief analysis examines the main achievements, dilemmas, and questions that surfaced during the Council meeting related to the economic model and the relevant payment mechanism, the Enterprise, and protection of the marine environment. It further outlines key outstanding issues that will re-appear on the Council's agenda when it meets in July 2019 . 
I warmly recommend reading this summary, in case you have not already done so. ${ }^{3}$

\section{b The International Tribunal for the Law of the Sea}

With respect to the International Tribunal for the Law of the Sea there has been an interesting development since the Tribunal was inaugurated in October 1996. We recognize the presence of two former Judges of the Tribunal: Helmut Türk of Austria and Rüdiger Wolfrum of Germany. Rüdiger Wolfrum was the President of the Tribunal 2005-2008.

So far, 26 cases have been submitted to the Tribunal. They involve wideranging subjects, such as maritime delimitation disputes, law of fisheries, the exploitation of the Area, the preservation and protection of the marine environment, and the arrest and detention of vessels.

The Tribunal also offers capacity-building programmes on the peaceful settlement of disputes under the Convention. So far, a series of thirteen regional workshops have been held in different regions of the world to provide experts from various States with practical information on dispute-settlement procedures before the Tribunal.

There is also an internship programme. Every year this programme gives twenty students from around the world the opportunity to gain a deeper understanding of the work and functions of the Tribunal. Since 2007 there is also a nine-month capacity-building and training programme on dispute settlement under the Convention for the benefit of young governmental officials and researchers.

An interesting summary of the work of the Tribunal at present appears in a statement by its President, Judge Jin-Hyun Paik, before the UN General Assembly on 11 December 2018. Since we have been addressing the issue of Biodiversity Beyond National Jurisdiction at our Conference, let me quote the following from the President's statement:

Allow me to say a few words about the current negotiations in the intergovernmental conference on an international legally binding instrument under the Convention on the conservation and sustainable use of marine biological diversity of areas beyond national jurisdiction.

I wish to draw the attention of the Member States of the United Nations to the importance of incorporating a robust dispute-settlement

3 Summary of the Twenty-fifth Annual Session of the International Seabed Authority (First Part): 25 February-1 March 2019. IISD Vol. 25 No. 185 available at http://enb.iisd.org/download/pdf/enb25185e.pdf. 
mechanism in the future instrument, as such a mechanism would ensure compliance with it. In this regard, consideration could be given to the possibility of incorporating Part $\mathrm{XV}$, on dispute settlement, of the Convention in the new instrument, following the example of the other agreements which have been concluded to implement provisions of the Convention. It might also be useful to consider the possibility of requesting the Tribunal for an advisory opinion in the new instrument. In this connection, you may recall that the Tribunal's jurisdiction comprises "all matters specifically provided for in any [agreement other than the Convention] which confers jurisdiction on the Tribunal" (article 21 of the Statute of the Tribunal). ${ }^{4}$

\section{c The Commission on the Limits of the Continental Shelf}

With respect to the Commission on the Limits of the Continental Shelf there has also been a very interesting development. ${ }^{5}$ One concern that the Meeting of States Parties to the Convention has had to address is the workload of the Commission in combination with the question of the ability of States, particularly developing States, to fulfil the requirements of article 4 of annex II to the Convention. ${ }^{6}$ Without going into detail about these elements, let me just say that as of 6 May 2019 the Commission had received go submissions containing information on the limits of the continental shelf beyond 200 nautical miles from the baselines from which the breadth of the territorial sea is measured.

As you are aware, in accordance with article 76 , paragraph 8 of the Convention, the Commission shall make recommendations to coastal States on such submissions. The limits of the shelf established by a coastal State on the basis of these recommendations shall be final and binding. So far, the Commission has adopted 31 recommendations under this provision. ${ }^{7}$

\section{2 The Division for Ocean Affairs and the Law of the Sea}

Finally, in addition to the three organs of UNCLOS, reference should be made to DOALOs, which, as I said, is part of the UN Office of Legal Affairs. This is a

4 The statement is available at https://www.itlos.org/fileadmin/itlos/documents/statements_ of_president/paik/2018_GA_111218_en.pdf.

5 See https://www.un.org/Depts/los/clcs_new/clcs_home.htm.

6 Reference is made to SPLOS/72 https://undocs.org/SPLOS/72 and to SPLOS/183 https://undocs.org/SPLOS/183.

7 See https://www.un.org/Depts/los/clcs_new/commission_submissions.htm 6 May 2019. 
very important entity — a focal point — in the field of the law of the sea and ocean affairs. According to the rules, the core functions of DOALOs consist of:

- Providing to States and intergovernmental organizations a range of legal and technical services, such as information, advice and assistance as well as conducting research and preparing studies relating to the United Nations Convention on the Law of the Sea (UNCLOS) and other agreements in the field of the law of the sea and ocean affairs;

- Providing substantive servicing to the General Assembly on the law of the sea and ocean affairs, including the United Nations Open-ended Informal Consultative Process established by the General Assembly in its resolution 54/33 in order to facilitate the annual review by the Assembly of developments in ocean affairs; the Meeting of States Parties to the Convention and to the Commission on the Limits of the Continental Shelf;

- Providing support to the organizations of the United Nations system to facilitate consistency with the Convention of the instruments and programmes in their respective areas of competence;

- Discharging the responsibilities, other than depositary functions, of the Secretary-General under the UNCLOS and the UN Fish Stocks Agreement;

- Conducting monitoring and research activities and maintaining a comprehensive information system and research library on the Convention and on the law of the sea and ocean affairs; and

- Providing training and fellowship and technical assistance in the field of the law of the sea and ocean affairs.

A visit to the DOALOS website is recommended. ${ }^{8}$

The Intergovernmental Conference on Marine Biodiversity of Areas beyond National Jurisdiction

May I also say a few words about the second session of the Conference that is engaged in the subject matter that we have discussed here at the World Maritime University, namely the Intergovernmental Conference on an international legally binding instrument under the United Nations Convention on the Law of the Sea on the conservation and sustainable use of marine biological diversity of areas beyond national jurisdiction. ${ }^{9}$ This session took place from

8 Available at http://legal.un.org/ola/div_doalos.aspx?section=doalos.

9 See https://www.un.org/bbnj/. Reference is also made to the following two press releases: https://www.un.org/press/en/2019/sea2101.doc.htm and https://www.un.org/press/en/ 2019/sea2102.doc.htm. 
25 March to 5 April 2019 under the presidency of Ambassador Rena Lee of Singapore, whom we are glad to see is among us here. Congratulations on the good result, Ambassador Lee!

Let me just say that the main part of the Conference was held in the format of four informal working groups on basically the same topics as has been discussed by the panels in our Conference, namely:

- Marine genetic resources, including questions on the sharing of benefits;

- Measures such as area-based management tools, including marine protected areas;

- Environmental impact assessments; and

- Capacity-building and the transfer of marine technology.

An informal working group on cross-cutting issues facilitated by the President was also set up.

An advanced and unedited version of the President's statement at the closing of the second session is available on the website of the Conference. ${ }^{10} \mathrm{An}$ nexed to the statement are also the oral reports of the facilitators of the five informal working groups. I recommend that you take part of this material if you have not already done so. The hope is that the result of the second session will enable the preparation of a draft of an instrument to be made available for negotiations at the third session of the Conference from 19 to 30 August 2019 .

I am sure that Ambassador Lee in her capacity as President of the session will find observations and analyses made at our Conference helpful. Personally, I noted in particular the discussions about the expressions "under the UNCLOs", "fully consistent with UNCLOs", "not undermine the existing system", and "no additional bureaucracy".

\section{The Present Geo-Political Situation}

Against this background, let us now look at the present geo-political situation. As I said at the outset, UNCLOS is certainly one of the most important treaties in the world. The development after its entry into force in 1994 has been very positive, even if one would hope that one day also the United States of America would be a party to it. However, a serious question is if this positive development will be affected by the present geo-political situation.

10 Availableathttps://www.un.org/bbnj/sites/www.un.org.bbnj/files/bbnj_-_igc2___presidents_ closing_statement_-_advance_unedited_version.pdf. 
It is sad to note that gradually in later years the most fundamental rules that we inherited from a generation that had experienced two world wars are being questioned or violated - even by Western democracies. Populism is on the rise. The behaviour of authoritarian State actors has entailed that international legal obligations have been ignored. The rule of law and fundamental human rights are being undermined.

Of particular concern is that the United States has withdrawn from the UN Human Rights Council and has left the so-called Paris Agreement- the global response to the threat of climate change-concluded in 2015. ${ }^{11}$ The United States has also withdrawn from the comprehensive, long-term solution to the Iranian nuclear issue, culminating in the Joint Comprehensive Plan of Action (JCPOA) concluded on 14 July 2015. ${ }^{12}$ States like Hungary and Poland are acting in flagrant violation of fundamental principles of the rule of law. The attack by Russia on Ukraine in 2014 is an obvious violation of the UN Charter. More examples of violations of international law in other parts of the world could be mentioned.

Furthermore, important contributions of science relating to the climate are not respected in a manner that one would expect in a civilised world. The question is whether this will also affect UNCLOS.

Basically, States parties to UNCLOS have respected the rules of the Convention, and disputes are being settled through negotiations or through arbitration or by the use of international dispute settlement mechanisms like ITLOS or the International Court of Justice. The organs of UNCLOS are functioning well. This is indeed positive. However, there are exceptions. One of the most serious examples is the manner in which China behaves in the South China Sea at present. This does not bode well for the future.

Another serious matter is the manner in which refugees that come across the Mediterranean are treated. We must also realise that climate change may in the future generate a flow of refugees in the world of such proportions that makes what we see today but a trickle in comparison.

With respect to the Arctic, the Arctic Council is an important institution. Established in Canada in 1996, it now has its secretariat based at Tromsø in Northern Norway. ${ }^{13}$ The Council is the leading intergovernmental forum promoting cooperation, coordination and interaction among the Arctic States,

11 Available at https://unfccc.int/process-and-meetings/the-paris-agreement/the-parisagreement.

12 See Security Council resolution 2231 (2015) and its Annexes A and B available at https:// undocs.org/S/RES/2231(2015).

13 See https://arctic-council.org/index.php/en/. 
Arctic Indigenous communities and other Arctic inhabitants on common Arctic issues, in particular on issues of sustainable development and environmental protection in the Arctic.

The cooperation within the Arctic Council has been very successful over the years, and every time all eight Arctic foreign ministers have met, they have issued a joint declaration. However, when the 11th ministerial meeting ended in Rovaniemi in Finland on 7 May this year, the meeting ended for the first time ever without such a declaration. The problem was that the United States refused to address the topic of "climate change" in the declaration. This was unbelievable. It is commonly known that rising $\mathrm{CO}_{2}$ levels have caused climate change that simply have to be addressed. Reference is made to the 1992 United Nations Framework Convention on Climate Change (UNFCCC) ${ }^{14}$ and the 2015 Paris Agreement that I just mentioned. ${ }^{15}$

Time does not allow me to go into detail here. However, I have addressed this question in another context focusing on Security Council reform and the effects that climate change will have on the question of international peace and security. ${ }^{16}$ There I also make a special reference to the situation in the Arctic.

The fact that the United States has left the comprehensive, long-term solution to the Iranian nuclear issue, the JCPOA that I just mentioned, is very serious indeed and has caused tensions at the international level. ${ }^{17}$ I have addressed also this question in another context. ${ }^{18}$ My conclusion is that one could question whether this withdrawal is legal after the endorsement of the agreement by the Security Council in its resolution 2231 (2015). Under all circumstances, in my opinion the United States is bound by the obligations under this resolution in the same manner as are all UN Member States.

One situation of special concern is the manner in which Morocco treats Western Sahara. In November 2001, when I served as the UN Legal Counsel, the Security Council asked for my opinion on "the legality in the context of international law, including relevant resolutions of the Security Council and the General Assembly of the United Nations, and agreements concerning Western Sahara of actions allegedly taken by the Moroccan authorities consisting in

\footnotetext{
14 Available at https://unfccc.int/resource/docs/convkp/conveng.pdf.

15 Supra, note 11.

16 See H. Corell, 'Security Council Reform - The Council Must Lead by Example' (2019) 22(1) Max Planck Yearbook of United Nations Law Online.

17 Supra, note 12.

18 Supra, note 16.
} 
the offering and signing of contracts with foreign companies for the exploration of mineral resources in Western Sahara". Having examined two contracts, concluded in October 2001, for oil-reconnaissance and evaluation activities in areas offshore Western Sahara, I came to the conclusion that if further exploration and exploitation activities were to proceed in disregard of the interests and wishes of the people of Western Sahara, they would be in violation of the principles of international law applicable to mineral resource activities in Non-Self-Governing Territories. ${ }^{19}$ Since I left the United Nations I have developed my thinking in this matter further, in particular since I think that the European Union is simply not following international law in the interaction with Morocco in this matter. ${ }^{20}$ It is of utmost importance that this question is resolved in accordance with international law.

\section{5}

\section{Conclusion}

In conclusion, let me say that UNCLOS is an extraordinary achievement negotiated under the auspices of the United Nations. The States Parties understand that it is important that they bow to this law, even if all of them do not fully observe pacta sunt servanda. The geo-political situation is troubling. But let us hope that the States Parties to UNCLOS realize how important it is that this treaty that governs 70 per cent of the surface of the globe is respected. There is so much to gain from a strict observance of UNCLOS.

As a matter of fact, what all this boils down to is respect for the rule of law at the national and international levels. Of particular importance is that politicians understand their responsibility for the rule of law. I therefore cannot resist making reference to a publication on the rule of law that is directed to politicians. It was inspired by a comment by former Chancellor Helmut Schmidt of Germany in a meeting of the InterAction Council of Former Heads of State and Government in 2008. The publication is some 45 pages in length and is freely available for downloading and printing from the web in 25 languages. ${ }^{21}$ Please

19 Letter dated 29January 2002 from the Under-Secretary-General for Legal Affairs, the Legal Counsel, addressed to the President of the Security Council, available at https://www. securitycouncilreport.org/atf/cf/\% ${ }_{7} \mathrm{~B}_{5} \mathrm{BFCF}$ B-6D27-4E9C-8CD3-CF6E4FF96FF9\% ${ }_{7} \mathrm{D} /$ s_2002_161.pdf.

20 See for example "The Responsibility of the UN Security Council in the Case of Western Sahara'. In: International Judicial Monitor, Winter 2015 Issue, available at http://www.judicialmonitor.org/current/specialcommentary.html.

21 Rule of Law - A guide for politicians. A Guide elaborated under the auspices of the Raoul Wallenberg Institute of Human Rights and Humanitarian Law at Lund University, 
google "Rule of Law—A guide for politicians" and you will find it. And please spread the message!

During our Conference here several speakers have made references to the UN Sustainable Development Goal 14: "Conserve and sustainably use the oceans, seas and marine resources" and its 10 targets. Rightly so!

However, let me point also to Goal 16: "Promote just, peaceful and inclusive societies". I am thinking in particular of two of its targets:

3. Promote the rule of law at the national and international levels and ensure equal justice for all;

and

5. Substantially reduce corruption and bribery in all their forms.

In my view achieving this goal is a precondition for achieving all the other goals.

Finally, on a very personal note: As a student, I used to sign on ships during my summer vacations. During four summers in the 1950s, I acquired 12 months of experience as a sailor in the Swedish merchant marine. One thing that I will never forget from this time is when I was standing at the helm taking orders from a pilot. When—after a few commands for "Starboard!" and "Port!"-the pilot determined that the ship was heading in the right direction, the command would be: "Steady as she goes!" It struck me that we should apply the same thought when we navigate UNCLOs towards the future: Steady as she goes! And the pilot should be Statesmanship!

Sweden, and the Hague Institute for the Internationalisation [now Innovation] of Law (HiiL), the Netherlands, available at https://rwi.lu.se/2017/o3/rule-law-guide-politicians. 